Schleiermacher's Early

Philosophy of Life:

Determinism, Freedom and

Phantasy

ALBERT BLACK WELL

Following the course of Schleiermacher's life from 1789-1804, this book develops its themes of determinism, freedom, and phantasy in relation to three principal writings: On Human Freedom (1792); On Religion (1799); and Soliloquies (1800). The book provides a thorough analysis of Schleiermacher's early thinking and an interpretive portrait of Schleiermacher as a young man, augmented by passages from his correspondence and incidents from his life.

Code: 020033

Price: Cloth $\$ 39.95(25.95)^{*}$

\title{
On the Glaubenslehre:
}

Two Letters to Dr. Lücke

FRIEDRICH D. E. SCHLEIERMACHER

James Duke and Francis Fiorenza, translators

The only English translation of

Schleiermacher's response to the critics of

The Christian Faith. Duke and Fiorenza's introduction and notes are indispensable aids to an understanding of the editions of

The Christian Faith.

Code: 010203

Price: Paper $\$ 9.95$ (6.95)

$\star(\quad)$ denotes member price

Payment must accompany all orders. MasterCard and Visa accepted. California residents add 6\% sales tax. Postage and Handling: $\$ 1.00$ for first item and $\$ .50$ for each thereafter; $\$ 4.00$ maximum. Outside U.S.: $\$ 2.00$ surcharge.

\section{SCHOLARS PRESS CUSTOMER SERVICES \\ P.O. BOX 4869, HAMPDEN STATION BALTIMORE, MD 21211}

